Jurnal Ilmu-Ilmu Peternakan 25 (2): 36 - 42

ISSN: 0852-3581

E-ISSN: 9772443D76DD3

CFakultas Peternakan UB, http://jiip.ub.ac.id/

\title{
Persepsi peternak sapi dalam pemanfaatan kotoran sapi menjadi bio- gas di Desa Sekarmojo Purwosari Pasuruan
}

\author{
Amang Fathurrohman ${ }^{1}$, Muh. Aniar Hari, $S^{2}$. Aminatuz Zukhriyah ${ }^{2}$ dan Moh. Awaludin \\ Adam $^{2,3}$ \\ ${ }^{1}$ Staf Pengajar Fakultas Agama Islam, Universitas Yudharta Pasuruan \\ ${ }^{2}$ Staf Pengajar Fakultas Pertanian, Universitas Yudharta Pasuruan \\ ${ }^{3}$ Staf Pengajar Akademi Perikanan Ibrahimy, IAI Ibrahimy Situbondo
}

ar.adam87@yahoo.com

\begin{abstract}
The aim of this research was to know the perception of cattle farmers towards dung utilization as biogas in Sekarmojo village, Purwosari, Pasuruan. The study used qualitative method with phenomenological approach. The data were collected from cattle farmers in Mojo hamlet, Sekar Mojo village, Pasuruan regency through interview, documentation and observation. The result showed that farmers in Sukorejo village did not utilize cow dung as biogas due to lack of knowledge about biogas. Instead of it, they prefered use it directly as fertilizer in their fields. Moreover, there were many negative perceptions such as village myth, expensive cost for biogas installation, worried of failure to sustain the biogas and traumatic of gas explosion.
\end{abstract}

Keywords : biogas, dung, village, farmer, cattle

\section{PENDAHULUAN}

Kebutuhan bahan bakar minyak (BBM) terus mengalami peningkatan seiring dengan meningkatnya proses industrialisasi. Kondisi ini tentu berpengaruh terhadap pola hidup ekonomi masyarakat sehingga akan mendorong meningkatnya kebutuhan energi. Padahal ketersediaan bahan bakar fosil sebagai pemasok utama sumber energi nasional semakin mahal dan terbatas (Yunus, 1995). Hal ini mengharuskan semua pihak berupaya mengembangkan dan memanfaatkan sumber daya energi yang dapat diperbaharui.

Usaha peternakan dapat memberikan manfaat yang besar jika dilihat dari perannya sebagai penyedia protein hewani. Namun, peternakan juga menjadi penyebab timbulnya pencemaran (Kristoferson dan Bokalders, 1991).
Hasil samping peternakan berupa limbah dalam skala besar dan semakin intensif akan menimbulkan masalah yang komplek. Selain bau yang tidak sedap, keberadaannya juga mencemari lingkungan, mengganggu pemandangan dan bisa menjadi penyakit. Seekor sapi berbobot $454 \mathrm{~kg}$ mampu menghasilkan $30 \mathrm{~kg}$ limbah feses dan urine setiap hari. Jika peternak memelihara 100 ekor sapi, maka jumlah limbah yang dihasilkan sebanyak 3 ton perhari dan akan mengganggu lingkungan sekitarnya.

Selama ini limbah feses dan urine banyak dimanfaatkan hanya sebagai pupuk oleh sebagian besar peternak dengan cara membawanya langsung ke kebun tanpa melalui pengomposan terlebih dahulu. Padahal feses tersebut masih panas dan bisa mengganggu pertumbuhan tanaman. 
Feses ternak bisa dikembangkan menjadi biogas sehingga peternak dapat mendapatkan gas sebagai bahan bakar (Soeharsono, 2007). Sisa fermentasi bahan organik dalam digester biogas bisa digunakan sebagai pupuk organik padat dann cair sehingga bisa mengurangi pencemaran lingkungan akibat tumpukan feses. Instalasi biogas dapat dibuat untuk skala rumah tangga dan skala perusahaan peternakan (Widodo dan Nurhasanah, 2004).

Sehubungan dengan hal tersebut, kegiatan instalasi biogas di daerah yang memiliki basis peternakan sapi sangat dibutuhkan untuk mencapai desa mandiri energi. Penelitian ini mengkaji persepsi peternak sapi tentang pemanfaatan kotoran sapi menjadi biogas di Dusun Mojo Desa Sekarmojo Kabupaten Pasuruan.

\section{MATERI DAN METODE}

Penelitian ini dilaksanakan pada pada bulan September-November 2015 di Dusun Mojo Desa Sekarmojo Kematan Purwosari Kabupaten Pasuruan. Metode penelitian yang digunakan adalah metode kualitatif dengan pendekatan fenomenologis. Data diperoleh dari para peternak sapi yang tinggal di lokasi penelitian melalui interview, dokumentasi dan observasi. Teknik analisis data menggunakan horizonalisasi, yakni mengembangkan kelompok makna menjadi berbagai tema deskripsi tekstural dan struktural serta tahap struktur invarian esensial (atau esensi), yaitu menulis deskripsi gabungan yang mempresentasikan "esensi" dari fenomena yang terfokus pada kesamaan pengalaman partisipannya (Cresswell, 2014).

\section{Prinsip pembuatan biogas}

Prinsip pembuatan biogas adalah adanya dekomposisi bahan organik secara anaerobik (tertutup dari udara bebas) untuk menghasilkan gas yang sebagian besar berupa metan (memiliki sifat mudah terbakar) dan karbondioksida yang disebut biogas. Proses dekomposisi anaerobik dibantu oleh sejumlah mikroorganisme terutama bakteri metan. Suhu yang baik untuk proses fermentasi adalah $30-55{ }^{\circ} \mathrm{C}$ karena pada suhu tersebut mikroorganisme dapat bekerja optimal dalam merombak bahan-bahan organik. Potensi biogas yang bisa dihasilkan tergantung dari bahan yang dipakai. Komponen-komponen biogas seperti yang ditunjukkan pada Tabel 1 .

Tabel 1. Komponen-komponen biogas

\begin{tabular}{clll}
\hline No & \multicolumn{1}{c}{ Nama gas } & \multicolumn{1}{c}{ Rumus kimia } \\
\hline 1 & Gas methan & $\mathrm{CH}_{4}$ & $54 \%-70 \%$ \\
2 & Karbondioksida & $\mathrm{CO}_{2}$ & $27 \%-45 \%$ \\
3 & Nitrogen & $\mathrm{N}_{2}$ & $3 \%-5 \%$ \\
4 & Hidrogen & $\mathrm{H}_{2}$ & $1 \%-0 \%$ \\
5 & Karbon monoksida & $\mathrm{CO}$ & $0.1 \%$ \\
6 & Oksigen & $\mathrm{O}_{2}$ & $0.1 \%$ \\
7 & Hidrogen sulfida & $\mathrm{H}_{2} \mathrm{~S}$ & Sedikit \\
\hline
\end{tabular}

Sumber: Widarto dan Sudarto, 1997

Prinsip kerja pembentukan biogas adalah pengumpulan feses ternak kedalam suatu tangki kedap udara yang disebut "digester" (pencerna). Gas yang timbul dari proses ini kemudian ditampung didalam digester. Penumpukan produksi gas akan menimbulkan tekanan sehingga dapat disalurkan ke rumah 
melalui pipa. Gas yang dihasilkan tersebut dapat dipakai untuk memasak menggunakan kompor gas atau untuk penerangan lampu petromaks. Gas yang dihasilkan sangat baik untuk pembakaran karena mampu menghasilkan panas yang cukup tinggi, apinya berwarna biru, tidak berbau dan tidak berasap sehingga kebersihan rumah tetap terjaga.

Selain untuk pembakaran, biogas juga digunakan sebagai gas alterna- tif untuk menghasilkan energi listrik. Kemampuan biogas sebagai sumber energi sangat tergantung dari jumlah gas metan. Setiap $1 \mathrm{~m}^{3}$ metana setara dengan $10 \mathrm{kWh}$. Nilai ini setara dengan 0,6 liter fuel oil. Sebagai pembangkit tenaga listrik, energi yang dihasilkan oleh biogas setara dengan lampu 60-100 watt selama 6 jam penerangan. Nilai kesetaraan biogas dan energi yang dihasilkan disajikan pada Tabel 2.

Tabel 2. Nilai kesetaraan biogas dan energi yang dihasilkannya

\begin{tabular}{ll}
\hline \multicolumn{1}{c}{ Aplikasi } & \multicolumn{1}{c}{$1 \mathrm{~m}^{3}$ biogas setara dengan } \\
\hline Penerangan & M0-100 watt lampu bohlam selama 6 jam \\
Memasak & Memasak 3 jenis makanan untuk 5-6 orang \\
Pengganti bahan bakar & 0,7 kg minyak tanah \\
Tenaga & Menjalankan 1 motor tenaga kuda selama 2 jam \\
Pembangkit tenaga listrik & Menghasilkan 1,25 kwh listrik \\
\hline
\end{tabular}

Sumber : Kristoferson dan Bokalders, 1991

\section{Pandangan masyarakat tentang bio-} gas

Biogas yang bahan dasarnya dari pemanfaatan kotoran sapi maupun kotoran manusia dalam pandangan masyarakat muslim di Indonesia masih menjadi perdebatan. Susmarkanto (2013) menyatakan bahwa sebagian besar santri tidak setuju dengan biogas karena perspektif berpikir santri banyak dipengaruhi oleh pemahaman tentang hakikat biogas dan konsekuensinya dari perspektif fiqih.

\section{Kajian yang membolehkan dan mengharamkan}

Kajian tentang biogas dalam perspektif hukum Islam sudah cukup banyak, salah satunya kajian di Situbondo yang menyimpulkan bahwa biogas dari kotoran hewan dalam Islam boleh dimanfaatkan dan tidak haram (Wawan dkk, 2012). Beberapa pesantren memilih sikap moderat dalam menjawab persoalan biogas, yakni memberikan jawaban yang membolehkan dengan dasar kajiannya dan mengharamkan juga dengan dasar hukumnya, sehingga para pembaca dipersilahkan memilih sendiri hukum yang akan dijadikan dasar pijakan sesuai dengan keyakinan masingmasing. Hal ini bisa dilihat dalam buku Ensiklopedi Fiqh Jawabul Masail Bermahzab Empat dari Pesantren Ngalah Purwosari Pasuruan yang memberikan dua alternatif jawaban, yakni jawaban yang membolehkan dan jawaban yang mengharamkan dengan dilengkapi dasar referensi hukumnya (Rizal, 2013). Hal yang sama juga diulas oleh Pesantren Tebuireng Jombang.

Perbedaan pandangan dan kajian tentang pemanfaatan biogas dengan memanfaatkan kotoran sapi akan berimbas kepada perbedaan persepsi masyarakat. Walaupun para peternak sapi memiliki potensi kotoran sapi yang berlimpah, namun jika masih memiliki 
persepsi negatif terkait dengan biogas pasti tidak ada kemauan untuk membangun instalasi biogas sebagai alternatif energi non fosil tersebut.

\section{HASIL DAN PEMBAHASAN}

\section{Potensi peternak sapi di Desa Sekarmojo \\ Desa Sekarmojo Purwosari}

Pasuruan ini terletak $\pm 30 \mathrm{~km}$ dari pusat kota Pasuruan ke arah barat dan merupakan salah satu daerah sentra peternakan sapi di Kabupaten Pasuruan (Badan Pusat Statistik Kabupaten Pasuruan, 2014). Desa ini belum memiliki sarana dan prasarana yang memadai sebagai sentra pengembangan ternak sapi dalam skala besar (baik sapi perah maupun sapi potong). Namun wilayah dan masyarakatnya sangat potensial sebagai sentra pengembangan peternakan sapi dalam skala besar karena tersedianya fasilitas lahan peternakan, pakan ternak sapi dan kultur masyarakat Sekarmojo yang kental dengan kehidupan peternakan sapi. Selain itu, peternakan sapi perah dan sapi potong juga merupakan usaha yang banyak menyerap tenaga kerja.

Meskipun terdapat banyak ternak sapi di Desa Sekarmojo, sebagian dari mereka adalah peternak penggarap yang tidak memiliki sapi sendiri dan hanya memelihara sapi milik orang lain. Peternak penggarap mendapatkan hasil kerjanya dari sistem "paron" atau bagi hasil. Keuntungan dihitung berdasarkan harga jual sapi pada umur tertentu dikurangi harga beli sapi dan biaya pembelian pakan tambahan (polard, bekatul atau empok).

Banyaknya potensi ternak sapi di Desa Sekarmojo akan menjadi sumber energi biogas yang merupakan salah satu sumber energi alternatif dalam memenuhi kebutuhan energi masyarakat secara mandiri. Sumber energi biogas ini juga akan berkembang seiring dengan perkembangan jumlah ternak sapi di Sekarmojo. Jumlah hewan ternak akan sebanding dengan jumlah kotoran yang dihasilkan. Perbandingan jumlah kotoran masing-masing hewan ternak dapat dilihat pada Tabel 3.

Tabel 3. Perbandingan jumlah kotoran masing-masing hewan ternak

\begin{tabular}{llccc}
\hline No & \multicolumn{1}{c}{ Jenis ternak } & $\begin{array}{c}\text { Jumlah kotoran } \\
\text { perhari }(\mathrm{kg})\end{array}$ & \multicolumn{2}{c}{ Prosentase kandungan } \\
\cline { 3 - 5 } & & 28 & 80 & Air \\
\hline 1 & Sapi potong & 28 & 80 & 20 \\
2 & Sapi perah & 35 & 83 & 20 \\
3 & Kerbau & 1.13 & 74 & 26 \\
4 & Kambing & 1.13 & 74 & 26 \\
5 & Domba & 3.41 & 67 & 33 \\
6 & Babi & 0.18 & 72 & 28 \\
7 & Ayam kampung / ras & 0.34 & 62 & 38 \\
8 & Itik & & &
\end{tabular}

Sumber: Widarto dan Sudarto, 1997

Tabel 3 menunjukkan bahwa jenis ternak yang paling utama dalam menghasilkan kotoran ternak untuk biogas adalah sapi potong, sapi perah dan kerbau. Lebih lanjut Widarto dan Sudarto (1997) menjelaskan bahwa jika setiap orang membutuhkan gas lebih kurang $0,5 \mathrm{~m}^{3}$ per hari cukup dipenuhi dari 1 ekor sapi atau 3 ekor babi atau 7 ekor kambing/domba. BPS Kabupaten Pasuruan (2013) menerangkan bahwa jumlah hewan ternak di Kecamatan 
Purwosari pada tahun 2013 sebanyak 8.112 dan sekitar $40 \%$ atau 3.224 ekor berada di Desa Sekarmojo. Jika diasumsikan setiap rumah tangga di Desa Sekarmojo terdiri dari 4 orang maka dapat disediakan $\pm 1.265 \mathrm{~m}^{3}$ biogas per hari atau dapat memenuhi kebutuhan gas bagi $316 \mathrm{KK}$ per hari.

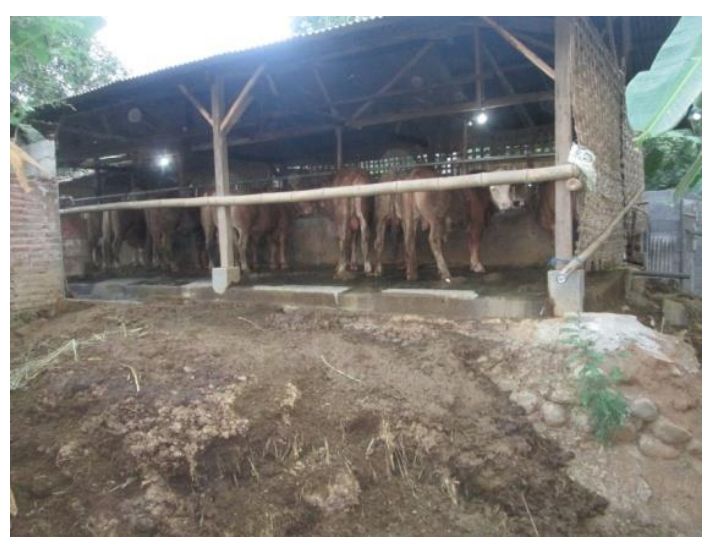

\section{Pengelolaan kotoran sapi}

Kotoran sapi merupakan bahan baku utama penghasil biogas. Namun, hasil observasi menunjukkan para peternak cenderung menumpuk kotoran sapi dan meletakkannya pada lahan kosong di pinggir kandangnya seperti yang tersaji pada Gambar 1.

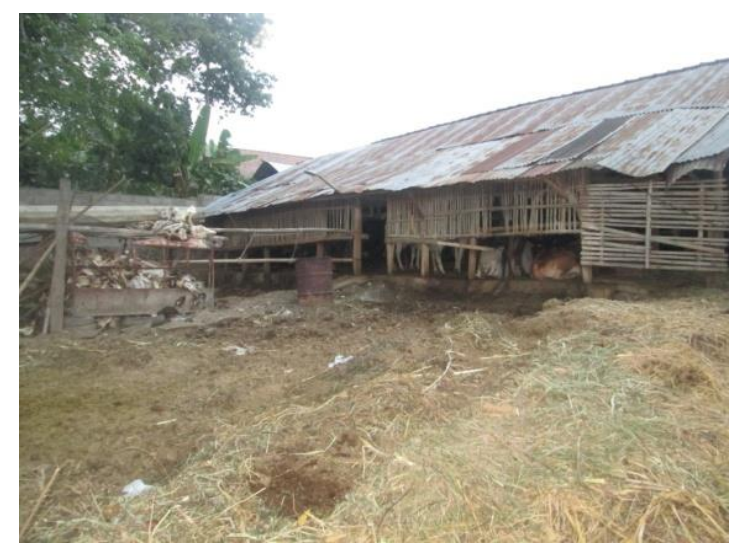

Gambar 1. Potensi kotoran sapi yang menumpuk dan belum termanfaatkan

Pak Dul dan Bu Sup sepasang suami istri yang mengelola 11 ekor sapi milik juragannya memisahkan kotoran sapi dengan urin, sehingga bau kotoran sapi sedikit berkurang dan tidak begitu mengganggu tetangga yang tinggal di sebelah kandang. Pembuangan urin disalurkan kedalam saluran khusus dan dibuang ke kebun dan sungai di belakang kandangnya, sedangkan kotoran sapinya ditumpuk dan dibiarkan mengering sebagai pupuk kandang bagi tanaman di ladang miliknya.

Hal ini menggambarkan bahwa kotoran sapi masih belum diolah secara optimal dan cenderung menyebabkan polusi udara bagi tetangga sekitarnya yang ditandai dengan bau kotoran yang cukup menyengat. Kondisi yang sama juga tidak jauh berbeda dengan peternak lain di Desa Sekarmojo.

\section{Persepsi penggunaan kotoran sapi sebagai biogas}

Hasil penelitian menunjukkan bahwa mayoritas peternak masih belum mengetahui fungsi dan manfaat biogas dari kotoran sapi. Hasil wawancara terhadap peternak menunjukkan bahwa pengetahuan mereka tentang biogas sangat terbatas. Sebagaimana diceritakan oleh Cak Dul tentang percakapannya dengan juragannya tentang biogas sebagai berikut: "Biogas niku nopo, damel nopo, kulo mboten semerap? (biogas itu apa, buat apa, saya tidak tahu?) kata juragannya. Kulo dewe nggih mboten semerap abah (saya sendiri juga tidak tahu, abah)", sahut Cak Dul. Percakapan tersebut menggambarkan bahwa mereka masih belum memiliki pengetahuan bahwa kotoran sapi bisa dimanfaatkan menjadi biogas. Terbatasnya pengetahuan ini memunculkan berbagai persepsi antara lain:

\section{Mitos masyarakat}

Walaupun tidak semua peternak sapi percaya dengan mitos, beberapa peternak mempercayai bahwa dengan memanfaatkan biogas yang dihasilkan 
dari kotoran sapi, maka akan bisa mendatangkan penyakit yang akan sulit disembuhkan sehingga para peternak merasa ketakutan untuk membangun instalasi biogas dari kotoran sapi.

Seorang responden bernama Bude Tun mengungkapkan bahwa penggunaan masakan dengan memanfaatkan biogas bisa menyebabkan penyakit yang sulit disembuhkan karena bahan baku utamanya dari kotoran sapi. Beliau menuturkan: "Ono sing ngomong, 'Ngonoan iku (penggunaan Biogas), engko lha wes kenek penyakit ora iso ditambani, lha wes loro ora kenek ditambani' (Ada yang bilang, jika menggunakan biogas, apabila nanti terkena penyakit, maka tidak bisa disembuhkan' lha kok iso (lho kok bisa Tanya Bude Tun) 'yo karena dari teletong', lah malah wedi ta" (ya karena terbuat dari kotoran sapi, ya saya menjadi takut).

Mitos tersebut menyebabkan keengganan para peternak sapi untuk membangun instalasi biogas dan lebih nyaman dengan menumpuk kotoran sapinya agar bisa digunakan sebagai pupuk di ladang dan kebun.

\section{Mahalnya proses instalasi biogas}

Puluhan peternak sapi di Dusun Mojo membuang kotoran sapinya tanpa ada upaya untuk membangun instalasi biogas. Menurut mereka, membangun instalasi biogas membutuhkan biaya yang mahal. Sedangkan pendapatan yang mereka terima dari hasil perkembangbiakan sapi atau hasil dari susu perahnya sudah habis untuk kebutuhan sehari-hari. "Oleh endi duwek, lha wong buruhane sak mono" (Dapat dari mana uang, sedangkan pendapatan dari kerja juga hanya segitu), begitu ungkapan Bude Tun terkait dengan pertanyaan tentang keinginan membangun instalasi biogas.
Hal senada juga diungkapkan oleh Cak Dul. Menurutnya, membangun instalasi biogas sangat berat. Apalagi pekerjaan mengembangkan ternak sapi ini tidak didanai oleh dirinya sendiri, tetapi kerjasama dengan orang lain. Sedangkan beliau sebagai orang yang memelihara sapi menyebut dirinya sebagai 'buruh ngarit dan buruh angon sapi.' Semua sapi yang dikelolanya milik orang lain, sedangkan Cak Dul bertugas mengembangkan dan mengelola sapi-sapi tersebut dan menyediakan lahan atau tempat kandang sapi. Dengan demikian, penghasilan yang didapatkan dari proses merawat sapi masih pas-pasan dan habis untuk kebutuhan sehari-hari. "Piro gawe biogas iki?" (berapa biaya pembuatan biogas ini?) begitu ungkapan Cak Dul yang menyatakan bahwa membangun instalasi sangat berat apabila dilakukan secara mandiri. Selanjutnya Cak Dul berkomentar "Lha opo sing digawe duwek. Lha wong nggawe kandang iki kulo didamelaken juragan. entek tigang doso enem (36) juta, kulo namung tenagane mawon" (uang dari mana untuk membangun instalasi biogas, membangun kandang sapi ini saja saya dibuatkan oleh juragan dan menghabiskan dana 36 juta, saya ini hanya di bagian tenaganya saja).

\section{Keberlanjutan instalasi biogas}

Ketakutan tentang keberlanjutan pemanfaatan biogas juga menjadi salah satu alasan keengganan membangun instalasi biogas karena dikhawatirkan ada masa-masa sulit sehingga pengembangan sapi menjadi terhambat atau bahkan bisa alih profesi. Maka biogas yang sudah dibangun dengan biaya "mahal" menjadi tidak termanfaatkan secara maksimal. Bu Tun mengungkapkan "Mbangun entek akeh, terus maringono ndak digawe" (Membangun instalasi biogas sudah 
habis banyak, tetapi selanjutnya sudah tidak terpakai lagi).

\section{Ketakutan dengan bahaya biogas}

Seringnya berita tentang meledaknya tabung gas elpiji juga membangun persepsi bahwa instalasi biogas juga bisa menjadi ancaman. Mereka merasa takut bahwa instalasi biogas yang sudah dibangun dengan kapasitas besar juga akan bisa berdampak bahaya dengan meledaknya gas sebagaimana berita-berita yang berkembang tentang tabung gas elpiji selama ini.

\section{KESIMPULAN}

Persepsi masyarakat Dusun
Mojo Desa Sekarmojo tentang
pemanfaatan biogas dari kotoran sapi
masih negatif karena masyarakat masih
belum mengetahui fungsi dan manfaat
biogas dari kotoran sapi.

\section{DAFTAR PUSTAKA}

Badan Pusat Statistik Kabupaten Pasuruan. 2013. Angka sementara hasil sensus pertanian Kabupaten Pasuruan 2013. BPS Kabupaten Pasuruan. Katalog BPS 5106002.

Badan Pusat Statistik Kabupaten Pasuruan. 2014. Kecamatan Purwosari Dalam Angka 2014. BPS Kabupaten Pasuruan. Pasuruan.

Cresswell, J. W. 2014. Penelitian kualitatif dan design riset: memilih di antara lima. Edisi ketiga. Pustaka Pelajar. Yogyakarta.

Kristoferson dan Bokalders. 1991. Penanganan dan pemanfaatan limbah padat. Penerbit
Mediyatama Sarana Perkasa. Jakarta.

Rizal, H. S. 2013. Ensiklopedia fiqih; jawabul masail, bermahzab empat. Pondok Pesantren Ngalah Pandean Sengonagung Purwosari Pasuruan. Hal. 84.

Soeharsono. 2007. Pengolahan limbah ternak untuk menghasilkan sumber energi alternatif dalam bentuk biogas di pedesaan. Prosiding Lokakarya Pengembangan Agribisnis Berkelanjutan di Pedesaan. LPPM UGM bekerjasama dengan Bappeda Kabupaten Kulon Progo dan BPTP Yogyakarta.

Susmarkanto. 2003. Sikap santri Tebuireng terhadap biogas. Jurnal Sain dan BPPT, Humas BPPT 2003; 5 (N5) Agustus:6674.

Wawan, J., Muhyiddin, K dan Ummi, K. 2012. Biogas tinja manusia dalam perspektif fiqih-kimia. Jurnal Islamica, Vol. 6, No. 2, Maret 2012, 389-402.

Widarto, L dan F. X. Sudarto. 1997. Membuat biogas. Penerbit Kanisius. Yogyakarta.

Widodo, T. W dan A. Nurhasanah. 2004. Kajian teknis teknologi biogas dan potensi pengembangannya di Indonesia. Prosiding Seminar Nasional Mekanisasi Pertanian, Bogor, 5 Agustus 2004. Balai Besar Pengembangan Mekanisasi Pertanian. Serpong.

Yunus, M. 1995. Teknik membuat dan memanfaatkan unit gas bio. Gadjah Mada University Press. Yogyakarta. 